\title{
ROBERT NOZICK'S RECTIFICATION PRINCIPLE AS A PLAUSIBLE COMPLEMENT TO THE FIGHT AGAINST CORRUPTION IN NIGERIA
}

\author{
Osita Nnajiofor* \\ \& \\ Geoffrey Chidi Onyebuchi* \\ http://dx.doi.org/10.4314/og.v15i1.7
}

\begin{abstract}
Nigeria, Africa's most populous nation has gained unprecedented global attention on account of her dismal records in corruption. The negative effects of these on her image are enormous. Notwithstanding her huge human and material potentials, she lies prostrate behind other developing nations. This paper examines corruption in Nigeria and its deplorable effect to the development and image of the country. It attempts to use Robert Nozick's entitlement principle as a prescription to complement the fight against corruption in Nigeria by the anti-graft agencies. To achieve this, this paper employs an analytic method to examine the meaning of corruption. It also attempts to review earlier solutions proffered by eminent scholars on the fight against corruption. Finally, it employs the rectification principle of Robert Nozick to complement the fight against corruption in Nigeria. This paper prescribes the need for value shift on the citizen's quest for material acquisitions and concludes that there is urgent need for rectification of all ill-gotten and unjust acquisitions by past and present office holders that are found guilty by the anti-graft agencies. This will bring sanity back to Nigeria's governance and polity.
\end{abstract}

\section{Introduction}

Nigeria is beset with enormous and unresolved challenges since precolonial times till the present post-colonial era. From the traumatic and devastating effects of colonialism and slavery which has lingered from time to the environmental degradations which is evident across the nation. Aside these unavoidable factors, there are other selfinflicted challenges that Nigerians have deliberately impose on themselves. Corruption is one of those self-imposed challenges facing Nigeria and has hindered her expected development when compared with countries like China and India. We used the word self- 
Nnajiofor \& Onyebuchi: Robert Nozick’s Rectification Principle...

imposed because of the "deeper" behavioral tolerance of corruption in all facets of Nigerian existential experiences. Asouzu (2004) opines that these challenges are some of the problems that individuals or groups insightfully, willingly, yet unintentionally and unknowingly imposed on themselves".

We equally chose the word "deeper" because of the attitudinal dimension and posture of corruption in Nigeria where it has assumed a cultural phenomenon. Oguejiofor (2016) elucidates this attitudinal and cultural phenomenon thus:

...that one can embezzle money; one is in fact even expected to embezzle money if he is in position to do so. The important caveat is that one must not be caught. If one is caught, powerful friends and political allies must be around to help; or must have enough money to engage the best lawyers who must be connected enough to bribe the judges.

On the helplessness and collaboration of anti-corruption agencies to aid corruption, Oguejiofor in addition says that, "We must add that lack of serious and well-coordinated anti-corruption activism has conspired to worsen the situation, and also ensured that every level of the Nigerian is neck- deep in corruption practices".(Ibid)

The anti-corruption agencies as presently instituted in the country have multiple versions such as Independent Corrupt Practices and other related offences Commission (ICPC), Economic and Financial Crimes Commission (EFCC) as well as the Code of Conduct Bureau. These bodies have been criticized for going after complex, competing, divergent and often overlapping mandates. To be fair, these bodies have made some appreciable successes in their fight against corruption. However, there are allegations from some quarters that these bodies are going after the tail of the monster of corruption rather than its head. For example, In October 2014, Observer Newspaper alleged that these bodies are used by the Presidency as instrument of blackmail or vendetta against political opponents. It also alludes that these agencies when they apprehend someone, instead of charging the person to court, the pockets of the offender would be charged and subsequently the case will abruptly end. 
It is a general knowledge that the damage of corruption has grievously tainted the image of Nigeria even beyond the shores of the country. For instance, in the published corruption index (CPI) OF Transparency International in 2014, Nigeria scored 136, occupying the same platform with Cameroun, Iran, Kyrgyzstan, Lebanon and Russia.

Also, BBC News of March, 2014 described Nigeria as a country where corruption is glorified and her officials honored, instead of total confiscation of their assets.

This was evident when former president Good luck Jonathan handed out awards to celebrate Nigeria's centenary. Nigerians and international community were shocked to their spine when they learnt that former President Sani Abacha was on the list of those to be honored. They were astonished on why a military dictator who had raped the nation's treasury to nothing was being celebrated.

It was the above deplorable actions and other related ones that made the likes of Collin Powell to describe Nigeria as "a nation of marvelous scammers, a string of partial victories against a seemingly unbeatable foe" (Nossier, 2012).

In the same vein, former British Prime Minister, David Cameron in one of the commonwealth anniversaries referred Nigeria as one of the countries that are "fantastically corrupt."

This paper duly acknowledges the efforts of the anti-corruption agencies and submits that applying Robert Nozick's rectification principle will complement their efforts in the fight against corruption. To achieve this, the first section will look at the meaning of corruption; the second section will look at the submissions of scholars and Nigerians to end this scourge in Nigeria. Lastly, this paper will consider Robert Nozick theory and its possible application in Nigeria to reduce the scourge of corruption and its devastating effects.

\section{The Concept of Corruption}

Despite the fact that corruption is a universal phenomenon and has attracted global attention in recent times, a generally accepted definition of the concept remains elusive.

The Encyclopedia Americana sees corruption as a disguised payment in the form of gifts, legal fees, employments, favor to relatives, social influences, or any relationship that sacrifices the public interest and welfare, with or without the implied payment of them. 
Nnajiofor \& Onyebuchi: Robert Nozick's Rectification Principle...

In Nigeria where oil is the main source of revenue, the revenue from oil is the yearning of most Nigerians. They refer to such money as "national cake". So the aspiration of most citizens is to get in to any of those "juicy" positions in order to be enriched without minding the consequences to the general public.

Lipset \& Lenz (2000) see corruption as efforts to secure wealth or power through illegal means, private gain at public expense; or a misuse of public power for private benefit. It is an anti-social behavior conferring improper benefits contrary to legal and moral norms, and which undermine the authorities to improve the living conditions of the people.

The successive coup and counter coup we have witnessed in Nigeria in the past few years falls into this category. They claim to overthrow the government for the interest of the people but in actual fact it was actually for their personal and group interest.

Khan (2006) defines corruption as "any act which deviates from the rules of conduct, including normative public domain, because of private regarding motives (that is non-public or general) such as wealth, power, status, etc.

Ruzindan (1999) asserts that corruption in Africa is a problem of routine deviation from established standards and norms by public officials and parties with whom they interact. Ruzindan identifies types of corruption in Africa as bribery, private gains, and other benefit to non-existent worker and pensioners (called ghost workers). The dishonest and illegal behavior exhibited especially by people in authority for their personal gain is corruption.

Implicit in the above definitions is the assumption that all corrupt acts are motivated by the desire to misuse the instrumentality of office or one's position in pursuit of private regarding interests, which may or may not be material, in violation of existing rules or norms.

Coming down to Nigeria which is the scope of this paper, corruption is defined from different perspectives. These perspectives are political, cultural administrative and legal dimensions.

The Anti-corruption law of Federal Republic of Nigeria (2000), sees corruption as spectrum of acts and not just the simple act of giving and receiving of bribes. Corruption covers acts such as: the use of one's office for pecuniary advantage, gratification, influence peddling, insincerity in advice with the aim of gaining advantage, 
attempt at gaining less than a full day's work for a full day pay, tardiness and slovenliness.

Enweremadu (1999) enumerates some of the manifestations of corruption in Nigeria to include - the inflation of contracts in return for huge kick-backs, fraud and falsification of accounts and vital documents, the ghost workers syndrome, examination malpractice in educational institutions, bribery and perversion of justice especially among the police. Crimes against the state in private sectors by multinationals in areas such as tax-evasion, over-invoicing of goods, foreign exchange swindling, hoarding and smuggling. Other areas of manifestations of corruption in Nigeria include fraud in the banking sector and illegal acquisition of landed property and a frightening degree of electoral fraud. The power sector fraud includes high levels of illegal impeachments, overthrow of government and rule of men syndrome instead of the rule of law.

The most comprehensive study of corruption in Nigeria according to Oguejiofor, where corruption is dubbed as a culture was done by Daniel Jordan Smith in his work, A Culture of Corruption: Everyday Deception and popular Discontent in Nigeria. Oguejiofor notes that Smith's work covers all dimensions of the life of Nigerians such as : e-mail scams, favoritism, 419, development scams including NGOs; Obasanjo's "Fair play Even among Robbers"; corruption in politics and democracy; electoral malpractice; fraud in the police force and vigilante groups like the Bakassi Boys; born again Christian; diabolical rituals; corrupt university structures in the form of supplementary admissions, monetized grades and concessionary admissions; fake drugs; bogus diagnosis; kleptocracy by contracts, etc. This is a comprehensive list of corruption acts in Nigeria but we must be quick to point out that corruption is not peculiar to born again Christians, in fact genuine born again Christians have demonstrated to be less corruptible in their various areas of placements. It is observed that corruption is a universal virus that is not peculiar to any race, religion, denomination, gender or academic status. This universal connotation can be traced to man's tendency to selfpreservation. This is also noticed in man's tendency to secure his interest first at the expense of others and also to survive better than others. In Nigeria where these exclusive tendencies, to borrow Asouzu's (2004) words, are not well managed the resultant effect is gross under development and misery 


\section{Prescriptions on the War against Corruption in Nigeria}

In desperate attempt to end the monster of corruption in Nigeria, most concerned Nigerian scholars have proffered solutions in a bit to eliminate corruption or at least reduce it to its barest minimum. Even foreigners are not left out of this concern for Nigeria's restoration. It is in this regard that Condoleezza Rice, once advised that Nigeria needs strong institutions and not strong men, in her word "as long as Nigeria does not institutionalize and de-personify the fight against corruption, the crusade to fight corruption would remain a huge joke". A famous Nigerian who has written extensively on African affairs and contributed in no mean degree to Nigeria's development is Prof Chinua Achebe. Chinua Achebe (2012:249) in his novel, "there was a country", echoed the same sentiment with Condolezza Rice on the need for a strong institution on the fight against corruption thus;

I foresee the Nigerian solution will come in stages. First we have to nurture and strengthen our democratic institutions- and strive for the freest and fairest election possible. That will place the true candidates of the people in office. Under the rubric of a democracy, a free press can thrive and a strong justice system can flourish. The checks and balances we have spoken about and the laws needed to curb corruption will then naturally find a footing....

Achebe (1983:253) noted also that corruption has grown because it is highly encouraged. In his book "The Trouble with Nigeria" suggests that "Nigerians are corrupt because the system they live under today makes corruption easy and profitable. They will cease to be corrupt when corruption is made difficult and unattractive". But years after the book was published, it is sad to note that the problem of corruption is probably worse than it has ever been, because of the massive way in which the Nigerian leaders are using the nation's wealth to destroy the country through unbridled looting. Due to the alarming rate of corruption in the country, Achebe cries out that corruption has passed the alarming stage and spilled into the fatal stage, and he notes that she will die if she continue to pretend that she is only slightly indisposed 
Odumegwu Emeka Ojukwu in his work "Because I am Involved" is of the opinion that wherever any case of corruption is noticed especially wealth accumulated through corrupt means, a thorough investigation should be carried out to know the source of it. If during or after the investigation the accused is found guilty, he or she should be prosecuted. But if after the investigation he or she is absolved of any charge, the accused should be absolved of any crime immediately. On the accumulation of wealth, Ojukwu opines that there is nothing wrong with wealth; the danger lies only in the methods of its acquisition. This method he says should be glaring and lawful. To this he says:

In a developing country where the structures are not yet taken root, it is prudent to suspect the acquisition of great corruptly acquired wealth. For this reason, I propose that wherever signs of wealth become conspicuous, the owner should not be considered guilty until he has proved himself innocent. If during the investigation, he produces the goose that lay his golden egg or points out the tree whose leaves are N20.00 notes, we should not hesitate in rejoicing with the wealthy and his good fortune. (The emphasis is ours)

But it is sad to note that the wealthy and powerful corrupt individuals who are guilty use their ill-gotten wealth to influence their judgments on the best lawyers who upturn the judgments in the law court. To us, this is one of the clog on the wheels of the anti-graft agencies in Nigeria today.

In his essay, Cultural values and the fight against corruption in Nigeria, Oguejiofor berates the anti- corruption agencies like EFCC and ICPC for increasing corruption rather than fighting against it. $\mathrm{He}$ proposed the need to change the focus of Nigerian values. This transvaluation of our national values should stern from those whom we call our heroes and their stance on corruption issues. He notes that heroes should serve as a source of inspiration to those growing up but the contrary is observed in Nigeria because our heroes are those who either have acquired large wealth regardless of the means or those who succeeded in occupying important positions. To really fight 
Nnajiofor \& Onyebuchi: Robert Nozick’s Rectification Principle...

corruption Nigerians should work on the impulses they are creating on the young ones. He distinguishes the types of impulses which are creative and possessive impulses. Quoting Bertrand Russell he opines that:

possessive impulses aim at acquiring or retaining private goods that cannot be shared; this center in the impulse of property... creative and constructive impulses, ... aim at bringing into the world or making available for use the kind of good in which there is no privacy or possession. Possessive impulses lead to "competition, envy, dominion, cruelty, and almost all the moral evils that infest the world." (Russell, 1977: 11-13)

He notes that the root cause of corruption and inordinate acquisition of wealth in Nigeria is the excess of possessive impulse in our country today. So he concludes his essay by encouraging the anti-graft agencies to consider our dynamic cultures and strives to change Nigeria's value system by introducing and encouraging more creative values than possessive values

Innocent Asouzu, (2004) in his classical work recognized the unflinching sacrifice of African leaders in attainment of independence but was quick to note that it was just a collective expression of the wish to freedom and self- determination. This independence he recounts is not the end, the actual turning point according to Asouzu "subsists in the African's return to the roots of his being where he defines his personal interests within the framework of the common good in response to the demands of the joy of being where he defines his personal interests within the framework of the common good in response to the demands of the joy of being".

For Nigeria to transcend from wish to authentic freedom and self-determination there is need for a thorough rehabilitation of her citizen's psyche to conform to the present changed contemporary situations. This transcendence should culminate into what Asouzu refers to as complimentary attitudinal change. In his words,

it is process through which individuals and human societies, at large seek to reposition minds in a way that makes it possible for them to anchor always their 
Ogirisi: a new journal of African studies vol. 152019

interests on the dictates of the common good within a universal complementary harmonious framework...the ego learns in the process of this form of self-actualization to identify its interests with the common good and to see the common good as a necessary condition towards its own actualization. (Asouzu, 2004: 252-253)

This complementary attitudinal change would lift personal autonomy over socio- economic conditions and extend all those means and mechanisms through which they seek to organize and express themselves as human beings in society and in the world. This change for him should be comprehensive and inclusive and should include those mechanisms where an African seeks to organize and express himself as a human being in the world. Nigerians should learn to give new meaning and understanding to corruption and see it as a concept which derives its meaning from the same foundation of legitimacy which gives meaning to the actions of all human beings in the society. Asouzu concludes that the radical form of attitudinal change is the measure Nigerians need to liberate her citizens from the constraints that had blinded them from realizing the ambivalence of their situations.

\section{Robert Nozick's Rectification Principle}

A Harvard professor, Robert Nozick in his most celebrated book, "Anarchy State and Utopia" was critical of John Rawl's difference principle, where Rawl postulates the idea of fair distribution of benefits and social cooperation. Entitlement theory is a theory of distributive justice and private property describing "justice in holdings" (Nozick; 1974).

Nozick proposes three (3) part 'Entitlement theory':

a) Person who acquires a holding in accordance with the principles of justice in acquisition is entitled to that holding.

b) A person who acquires a holding in accordance with the principle of justice in transfer from someone else is entitled to the holding.

c) No one is entitled to a holding except by (repeated) application of (a) and (b).

Holdings are simply to be understood as instances of ownership of some property or resources. Any theory of distributive justice must 
Nnajiofor \& Onyebuchi: Robert Nozick's Rectification Principle...

have some principles that allow us to distinguish just holding from unjust holdings. Nozick offers the following series of principle The principle of just acquisition concern the legitimate first moves. Acquisition here means first or original acquisition of goods which are owned either by nobody or else inclusively, by everyone in common.

The principle of just transfer concerns "the legitimate means of moving from one distribution to another." Subject matter here includes voluntary exchanges, including sales and purchases as well as gifts and donations.

Principles of Rectification operate when holdings are illegitimate in respect of acquisition or transfer. They would require, for example that stolen goods be returned to the legitimate owner. If we apply the entitlement theory where the ownership of your possession is challenged, you vindicate your possession by the application of the principles of justice in transfer when you give evidence of the purchase. Had the goods turned out to be stolen or kept following a loan, restitution to the owners would be prescribed by application of justice in rectification. As Nozick (1974: 231) points out "if the current distribution of holdings are as a result of unjust acquisition, then a distribution which would have arisen had the transaction been just must be rectified."

The original owner here is the Nigerian state and all the state apparatus. Many have acquired or transferred the holdings belonging to the generality of Nigerians for their private ends. This is why this essay considers this third principle as a prerequisite in reducing the rate of corruption in Nigeria.

Philosophy is a rigorous and critical enterprise, which is why Robert Nozick's rectification principle has not gone without some scathing attacks and evaluations from philosophers. Philosophers observe the impossibility of applying Nozick's rectification principle in variety of cases. For instance, a case where an injustice is meted out and the person died in the process and nothing whatever was done to make that person in particular better off than he was. How far can we go when deciding to rectify injustices already meted to him? In the area of land acquisition; for instance, the truth is that if we go far enough we will find some of our ancestors who were oppressed and their lands unjustly taken. How do we rectify these injustices? Nnajiofor and Ifeakor (2016) observe that many corporate assets have been 
constructed on some of the stolen or unjustly acquired lands and huge investments made on those lands. How then do we compensate the original owners of these lands? This is why rectification of these past injustices and transgressions of indigenous properties is important. Nevertheless, some of these rectifications are currently achieved through fiscal compensation and affirmative schemes.

The resource constraints limiting the sum available for restitution is another criticism leveled against Nozick's rectification principle. If the oppressor destroys economic value, the sum total of claims may exceed the resources available for rectification. Pogany (1997) notes that "in the former Soviet Union, there is not nearly enough to give everyone "what they would have had", had Lenin instituted liberal capitalist democracy, nor can ex-dictator of Haiti give back all the economic value they have destroyed, or even a sizeable fraction thereof....the total wealth of Hungary was not greater than the value of the assets confiscated from Hungarian Jews during the second world war".

Applying Robert Nozick's Rectification principle may be a tall order especially on how far backward the anti-graft agencies can go to rectify Nigerian looted properties and funds. Will it not be an unjust venture for the anti-graft agencies to concentrate their anticorruption fight only on one administration? Some analysts are of the opinion that their anti-corruption fight should start from 1960 i.e since after independence till date to give their fight against corruption a comprehensive and a holistic outlook. Also, how do these agencies rectify the corrupt possessions of the dead and long forgotten corrupt Nigerians? Will it not amount to gross injustice if they go after the relatives of the dead corrupt politicians like the notorious Abacha's loot? Also, in a situation where a corrupt individual sold his investments to another and later died, who will the anti-graft agency go after; will they go after the buyer or the demised original owner? Despite the above weaknesses, there are some salient principles to be derived from the Nozick's rectification principles. This essay strongly submits that as a complement to the contributions and strategies of the anti-graft agencies, Robert Nozick's Rectification will be useful to the anti-graft agencies if it is employed in their fight against corruption. Our proposition is that before any appointment or clearance to any elective post is made, the person must have undergone a blind evaluation. On the process, if any trace of corruption is leveled against 
Nnajiofor \& Onyebuchi: Robert Nozick’s Rectification Principle...

any prospective appointees or aspirants, such a person must step down and should be constrained to restore all the unjust acquisitions in his possession by the anti-graft agency. This process will discourage corrupt individuals into any elective positions and also those seeking political or corporate positions. The anti-graft agencies should also be empowered by the government with the necessary financial and legal arsenal. Autonomy is also very necessary for their optimal efficiency. This empowerment will give them the will power to pursue a holistic justice both in acquisition, transfer and rectification.

\section{Conclusion}

We have considered the task of the anti-graft agencies which are enormous. To undergo an enormous task, an enormous responsibility is required. Due to the nature of corruption that has taken a deeper root in Nigerian system, it will require gradual, systemic and radical step to uproot it from Nigeria blood stream. To preserve the nation from imminent moral and general collapse, there is urgent need to work on the Nigerian value system. The culture of sudden material quest and empirical immediacy is a serious threat to Nigeria's development. To have a meaningful impact on the fight against corruption, the campaign should be taken back to our education system: crèche, nursery, primary, secondary and university system, and other non-education systems. The task of this campaign is to engage in what we call a "value shift." There is urgent need to overhaul our Nigeria we know value system. This Nigeria we know syndrome borders on our insatiable appetite for materialism. This essay submits that applying Robert's Nozick's rectification principle can complement the efforts of the anti-graft agencies in dealing with the monster of corruption in Nigeria.

*Osita Nnajiofor, PhD, Department of Philosophy, Nnamdi Azikiwe University, Awka, Anambra State - Nigeria

*Geoffrey Chidi Onyebuchi, PhD, Department of Educational Foundations, Faculty of Education, Nnamdi Azikiwe University, Awka, Anambra State - Nigeria. 


\section{References}

Achebe C. (2012). There Was a Country, A Personal History of Biafra; London, Penguin Books. 2012. P.249.

(1983). The Trouble with Nigeria. Enugu: Fourth Dimension Publishing Co, p.253.

Anti - Corruption Law of the Federal Republic of Nigeria (2000) Times Press Ltd; Daily Times Premises, Agidingbi, Lagos.

Asouzu, I, (2004). The Method and Principles of Complementary Reflection in and Beyond African Philosophy. University of Calabar Press: Calabar.

Russell, B. (1977). Political Ideals. George Allen and Unwin: London.

Enweremmadu, D. (1999). The Struggle against Corruption in Nigeria: The Role of the National Anti- Corruption Commission under the 4th Republic. .41-66

Khan, M. (2006). Typology of Corrupt Transaction in Developing Countries" Jos 1996, Bulletin; 27(2) pp. 12-21.

Lipset, S.M, \& Lenz, G.S (2000). Corruption, Culture, and Markets, in Culture in Anowai (ed) Corruption; The Bane of Nigeria's Development" at Pope John Paul Annual Memorial Lecture Series (6) p. 95-10.

Naira-Land. (2012). "The True Story About Corruption in Nigeria; Hypocrisy Is the Order the Day" May 14. 2012.

Nnajiofor G and Ifeakor C. (2016). Robert Nozick's Entitlement theory of Justice: A Critique. In Ogirisi a new journal of African studies, vol 12, 2016. Awka, Lumos Nig, Ltd. P 178,

Nossier, A. (2012) The Fighter of Corruption In Nigeria Considers Next Steps: New York Times, Nov 22, 2013. 
Nnajiofor \& Onyebuchi: Robert Nozick's Rectification Principle...

Nozick, R. (1974). Anarchy State and Utopia (New York, Basic Books, 1974)

Oguejiofor, J. (2016). Cultural Values and the fight against corruption in Nigeria. De Victorious Son Publication: Awka.

Ojukwu. O. (1989). Because I am Involved, Spectrum Books Limited, Ibadan

Transparency International. (2016). Corruption Perception index, quoted by Oguejiofor (ibid)

Smith, D. J. (2007). A culture of corruption: Everyday deception and popular discontent in Nigeria. Princeton University Press: Princeton. 